\section{Mspl polymorphism of the human CYP2E gene}

F.Uematsu ${ }^{1,2}$, H.Kikuchi ${ }^{1}$, T.Abe ${ }^{2}$, M.Motomiya ${ }^{2}$,

T.Ohmachi ${ }^{1}$, I.Sagami ${ }^{1}$ and M.Watanabe ${ }^{1}$

${ }^{1}$ Department of Cancer Chemotherapy and Prevention and 2 Department of Internal Medicine, The Research Institute for Tuberculosis and Cancer, Tohoku University, Sendai 980, Japan

Source/Description: Oligonucleotide primers were used to amplify a 480 bp segment of cytochrome P450IIE1 (CYP2E) intron VI (1) (GenBank accession no. J02843).

PCR Primers:

5' GTGCTGAACACTGGTACTCT 3'

5' CTGACTGGCCTGTTTGCATG 3'

Polymorphism: MspI detects a two-allele polymorphism with bands at $0.47 \mathrm{~kb}$ or $0.3 \mathrm{~kb}$ and $0.2 \mathrm{~kb}$.

Frequency: Studied in 36 unrelated Japanese

allele G1 $\quad(0.47 \mathrm{~kb}) \quad 0.89$

allele G2 (0.3 kb and $0.2 \mathrm{~kb}) \quad 0.11$

Frequency of Heterozygosity: 0.22 .

Chromosomal Localization: 10 (1).

Mendelian Inheritance: Autosomal co-dominant shown in one informative family.

Other Comments: This polymorphism was first detected using the cDNA probe $\lambda$ hPD4 $(2,3)$. The PCR reaction was performed on $2 \mu \mathrm{g}$ of genomic DNA using 100 pmoles of each primer and 2.5 units of Taq polymerase. Samples were cycled thirty times at $94^{\circ} \mathrm{C}$ for $1 \mathrm{~min}, 50^{\circ} \mathrm{C}$ for $2 \mathrm{~min}$ and $72^{\circ} \mathrm{C}$ for $3 \mathrm{~min}$.

Acknowledgements: We thank Drs T. Kamataki and M. Komori for providing the $\lambda$ hPD 4 probe. This work was supported by Grants-in-Aid from the Ministry of Education, Science and Culture.

References: 1) Umeno,M. et al. (1988) Biochemistry 27, 9006-9013. 2) Komori,M. et al. (1989) Arch. Biochem. Biophys. 272, 219-225. 3) Uematsu,F. et al. (1991) Nucl. Acids Res. 19, 2803.

\section{Dinucleotide repeat polymorphism at the human gene for insulin-like growth factor I (IGFI)}

M.H.Polymeropoulos, D.S.Rath, H.Xiao and C.R.Merril National Institute of Mental Health Neuroscience Center, St Elizabeths Hospital, Room 131, 2700 Martin Luther King Avenue, Washington, DC 20032, USA

Source/Description: The polymorphic $(\mathrm{CT})_{\mathrm{n}}$ repeat begins at base pair 140 of the human gene for insulin-like growth factor I on chromosome 12q23 (1). The polymorphism can be typed using the polymerase chain reaction (PCR) as described previously (2). The predicted length of the amplified sequence was $187 \mathrm{bp}$.

Primer Sequences:

TTGTGTCAACTGCTGATATG (CT strand)

AACCAAAACATCATTCCCTA (GA strand)

Frequency: Estimated from 78 chromosomes of unrelated individuals. Heterozygosity Index $=53 \%$. PIC $=0.52$.

$\begin{array}{llll}\text { Allele (bp) } & \text { Frequency } & \text { Allele (bp) } & \text { Frequency } \\ \text { F1 207 } & 0.01 & \text { F7 195 } & 0.01 \\ \text { F2 205 } & 0.03 & \text { F8 193 } & 0.05 \\ \text { F3 203 } & 0.03 & \text { F9 191 } & 0.03 \\ \text { F4 201 } & 0.03 & \text { F10 189 } & 0.67 \\ \text { F5 199 } & 0.10 & \text { F11 173 } & 0.01 \\ \text { F6 197 } & 0.03 & & \end{array}$

Mendelian Inheritance: Co-dominant segregation was observed in two informative families.

Chromosomal Localization: The human gene for insulin-like growth factor I has been assigned to chromosome 12q23 (3).

Other Comments: The PCR reaction was performed on $80 \mathrm{ng}$ of genomic DNA using 100 pmoles of each oligonucleotide primer. The samples were processed as described (4) except that the denaturation cycle at $94^{\circ} \mathrm{C}$ was extended to 1.4 minutes. The dinucleotide repeat was based on a $(C T)_{16}$ sequence.

References: 1) Dull,T.J. et al. (1984) Nature 310, 777-781. 2) Weber,J.L. and May,P.E. (1989) Am. J. Hum. Genet. 44, 388-396. 3) Brissenden,J.E. et al. (1984) Nature 310, 781 - 784. 4) Weber,J.L. et al. (1990) Nucl. Acids Res. 18, 4637.

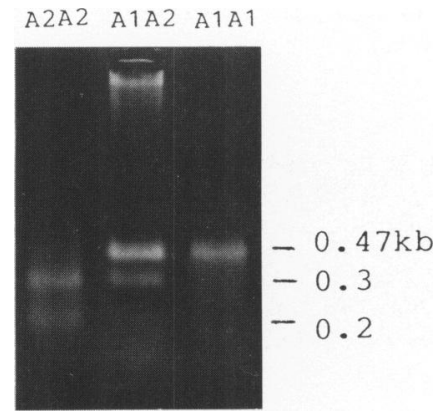

